\title{
Tumor Necrosis Factor Expression in Human Epithelial Tumor Cell Lines
}

\author{
David R. Spriggs, Kyoko Imamura, Christina Rodriguez, Eric Sariban, and Donald W. Kufe \\ Laboratory of Clinical Pharmacology, Dana-Farber Cancer Institute, Boston, Massachusetts 02115; \\ and Harvard Medical School, Boston, Massachusetts 02115
}

\begin{abstract}
Tumor necrosis factor (TNF) is a monokine with in vitro cytotoxicity for some but not all tumor cells. The basis for sensitivity and resistance to the antitumor effects of this agent remains unclear. The present studies have monitored the effects of TNF on 14 epithelial tumor cell lines. Eleven of these cell lines were resistant to the growth inhibitory effects of TNF (50\% inhibitory concentration $>1,000 \mathrm{U} / \mathrm{ml}$ ). 12 of the 14 tumor cell lines has detectable levels of high affinity cell surface TNF binding sites, thus suggesting that resistance was not often due to the absence of cell surface TNF receptors. Northern blot analysis demonstrated that three of the eleven resistant cell lines expressed detectable levels of TNF mRNA. Furthermore, both sensitive and resistant epithelial tumor cells had the capacity to express TNF transcripts in the presence of the protein synthesis inhibitor, cycloheximide. Finally, the presence of TNF expression at the RNA level is shown to be associated with the production of a TNF-like protein in the resistant $\mathrm{Ov}-\mathrm{D}$ ovarian carcinoma cells. These findings suggest that certain human epithelial tumor cell lines inherently resistant to TNF also express this cytokine.
\end{abstract}

\section{Introduction}

Tumor necrosis factor (TNF) ${ }^{1}$ is a polypeptide cytokine with a variety of in vitro and in vivo effects. TNF was first identified in the serum of mice challenged with endotoxin after BCG innoculation (1). Infusions of serum containing TNF into untreated mice induced hemorrhagic necrosis of transplanted subcutaneous tumors. The purified TNF protein was also found to be cytotoxic or cytostatic for a number of human and murine tumor cell lines in vitro and in vivo (1).

TNF has been shown to mediate certain effects in normal cells. TNF functions as a growth factor for human diploid fibroblasts in vitro and activates a variety of immune effector cells (2-5). Polymorphonuclear neutrophils are stimulated by TNF to increase respiratory activity, phagocytosis, superoxide formation, and antibody-dependent cellular cytotoxicity (3-5). Eosinophil cytotoxicity for Schistosoma mansoni larvae is also enhanced by TNF (6). Resting macrophages produce interleukin 1 and prostaglandin $\mathrm{E}_{2}$ after TNF exposure, and TNF has been shown to be an important effector molecule for

Received for publication 23 December 1986 and in revised form 25 June 1987.

1. Abbreviation used in this paper: TNF, tumor necrosis factor.

J. Clin. Invest.

(C) The American Society for Clinical Investigation, Inc. $0021-9738 / 88 / 02 / 0455 / 06 \$ 2.00$

Volume 81 , February $1988,455-460$ macrophage cytotoxicity after activation $(7,8)$. TNF also promotes bone resorption, stimulates the production of granulocyte-macrophage colony-stimulating factor, inhibits lipogenic gene expression in adipocytes, and stimulates the production of collagenase and prostaglandin $\mathrm{E}_{2}$ by synovial cells (9-12). Endothelial cells exposed to TNF have enhanced procoagulant activity and suppression of the protein C pathway (13). Passive immunization against TNF can protect mice from the lethal effects of endotoxin, suggesting that TNF is an important mediator in the physiology of endotoxic shock (14). Administration of recombinant TNF to rats elicits many of the pathophysiologic changes associated with endotoxemia including acidosis and respiratory arrest (15).

The antitumor effects of TNF are not well understood. Direct cytotoxicity is apparently mediated by specific binding to high affinity cell surface receptors. However, the presence of cell surface receptors is not sufficient for cytotoxicity since normal cells and TNF-resistant tumor cells also have high specificity cell surface receptors $(16,17)$. The cytotoxic effects of TNF appear to be cell cycle specific. TNF causes accumulation of cells in $G_{2}$ phase and cytolysis in the late stages of mitosis (18). Inhibitors of protein synthesis and RNA synthesis result in increased TNF cytotoxicity, and L929 cells that are not rapidly proliferating are more sensitive to the cytotoxic effects of this agent $(19,20)$. Combinations of TNF and either alpha or gamma interferon show synergistic cytotoxicity for certain human tumor cell lines (21). Interferons increase the number of cell surface TNF receptors, but this observation may not be related to the cytotoxic synergy $(19,21)$.

The basis for the differential effects of TNF against certain malignant cells and normal cells remains uncertain. Furthermore, it is unclear why certain malignant cell lines are apparently resistant to the cytotoxic effects of TNF. Recent reports indicate that murine L929 cells and human ZR-75-1 breast carcinoma cells selected for resistance to TNF produce and secrete TNF protein $(22,23)$. The present study has examined resistance to TNF cytotoxicity in human epithelial tumor cells and TNF production by some of these resistant cell lines.

\section{Methods}

Cell culture. L929 cells (wild type and a subculture resistant to TNF; kindly provided by Dr. L. Old, Sloan-Kettering Institute for Cancer Research, New York, NY) were grown in Eagle's minimum nonessential medium supplemented with $0.1 \mathrm{mM}$ nonessential amino acids, $0.30 \mathrm{mg} / \mathrm{ml} \mathrm{L}$-glutamine, $100 \mathrm{U} / \mathrm{ml}$ penicillin, $100 \mu \mathrm{g} / \mathrm{ml}$ streptomycin, and $10 \%$ heat inactivated FCS. Four human ovarian cell lines (Ov-A, Ov-D, Ov-M, and Ov-S), provided by Dr. R. Knapp, Brigham and Womens's Hospital, Boston, MA, were grown in Dulbecco's modified essential medium supplemented with $0.30 \mathrm{mg} / \mathrm{ml} \mathrm{L-glutamine,}$ $100 \mathrm{U} / \mathrm{ml}$ penicillin, $100 \mu \mathrm{g} / \mathrm{ml}$ streptomycin, $10 \mu \mathrm{g} / \mathrm{ml}$ insulin, and $10 \%$ heat inactivated FCS. Human gastrointestinal tumor cell cultures (ST-1, Co-1), provided by Dr. T. Ohno, Jikei University, Tokyo, Japan, were grown in RPMI 1640 medium with $0.30 \mathrm{mg} / \mathrm{ml} \mathrm{L-gluta-}$ mine, $100 \mathrm{U} / \mathrm{ml}$ penicillin, $100 \mu \mathrm{g} / \mathrm{ml}$ streptomycin, and $10 \%$ heat-in- 
activated FCS. The human squamous carcinoma cells (SCC-25; provided by Dr. E Frei, Dana-Farber Cancer Institute) were grown in RPMI 1640 with 20\% FCS. Three human breast carcinoma lines (ZR-75-1, MCF-7, and BT-20) and four human lung carcinoma lines (Calu-3, Calu-6, NCI-69, and A549) were obtained from the American Type Tissue Culture Collection and were grown as previously described.

Toxicity assays. Sensitivity to TNF was determined using a 96-well plate assay. 10,000 tumor cells were plated into each well and incubated for 5-7 d with increasing concentrations of TNF. The cells were then fixed with $2.5 \%$ glutaraldehyde, washed and stained with $0.05 \%$ methylene blue. After $5 \mathrm{~min}$, the plates were washed and the dye released with $0.33 \mathrm{~N} \mathrm{HCl}$. The absorbance of each well was determined with an automated plate reader (Bio-Rad Laboratories, Richmond CA). The effect of TNF was determined by comparing absorbance of TNF-treated cells with that obtained for untreated control cells.

Radiolabeling of TNF. Human recombinant TNF (PAC-4D) was provided by Asahi Chemical Industry America, Inc., New York, NY (24). The TNF protein was labeled with ${ }^{125} \mathrm{I}$ by the Iodogen method and purified by gel filtration (16). The labeled protein was homogenous by SDS-PAGE (Fig. $1 A$ ). The ${ }^{125}$ I-labeled TNF had a specific activity of $3.01 \times 10^{5} \mathrm{cpm} / \mathrm{pmol}$ protein monomer.

TNF binding assays. Binding assays with ${ }^{125} \mathrm{I}-\mathrm{TNF}$ were performed in triplicate on monolayers of epithelial cells $\left(2 \times 10^{5}\right.$ cells/well $)$ in 24-well Costar plates. The cells were incubated with 40 pM ${ }^{125} \mathrm{I}-\mathrm{TNF}$ for $120 \mathrm{~min}$ at $4^{\circ} \mathrm{C}$ in the appropriate medium with $10 \% \mathrm{FCS}$. The cells were then washed three times with ice-cold PBS and lysed with $2 \%$ SDS. The entire lysate was counted for radioactivity. Specific binding was determined as the difference between total binding and "nonspecific binding" in the presence of a 100 -fold excess of unlabeled TNF protein.

Measurement of TNF levels. Determinations of TNF protein were made using cell culture supernatants and cell lysates. Immunologic activity was determined by analysis in the previously described ELISA, which used two monoclonal antibodies reactive with distinct epitopes on the TNF molecule (25). Biological activity was determined in a $\mathrm{L}$ cell cytotoxicity assay standardized with recombinant TNF. $1 \mathrm{U}$ in the ELISA was defined as the amount of TNF required for $50 \%$ cytotoxicity in the L929 cells (22).

Northern blot analysis. Total cellular RNA was collected from all human tumor cell lines utilizing the guanidine thiocyanate/cesium chloride method as previously described (26). The purified RNA (20 $\mu \mathrm{g})$ was analyzed by electrophoresis through $1 \%$ agarose-formaldehyde gels followed by Northern blot transfer to nitrocellulose paper. The TNF probe (generously provided by Dr. P. Ralph, Cetus Corp., Emeryville, CA) was nick translated to a specific activity of $\sim 5 \times 10^{8}$ $\mathrm{cpm} / \mu \mathrm{g}$ DNA (27). The nitrocellulose filters were prehybridized at $42^{\circ} \mathrm{C}$ for $16-24 \mathrm{~h}$ in buffer consisting of $50 \%$ formamide, $5 \times$ standard saline citrate (SSC) $\left(0.15 \mathrm{M} \mathrm{NaCl} ; 0.015 \mathrm{M} \mathrm{Na}_{3}\right.$ citrate $=1 \times$ SSC $), 0.1 \%$ SDS, $5 \times$ Denhart's solution, and $200 \mu \mathrm{g} / \mathrm{ml}$ salmon sperm DNA. The filters were then incubated for an additional $24 \mathrm{~h}$ in the same buffer with $2 \times 10^{6} \mathrm{cpm} / \mathrm{ml}$ of labeled probe. After hybridization the blots were washed twice in $0.1 \%$ SDS, $2 \times$ SSC for $60 \mathrm{~min}$ at room temperature, and then washed two more times with $0.1 \%$ SDS, $0.1 \times$ SSC at $55^{\circ} \mathrm{C}$. The blots were then dried and exposed to $\mathrm{x}$-ray film for $10 \mathrm{~d}$ with an intensifying screen at $-70^{\circ} \mathrm{C}$.

Metabolic labeling of TNF. Confluent epithelial cells were incubated overnight in leucine-free RPMI 1640 medium with $16 \mu \mathrm{Ci} / \mathrm{ml}$ of $\left[{ }^{3} \mathrm{H}\right]$ leucine (140.2 Ci/mmol, New England Nuclear, Boston, MA). The cells were collected by scraping and lysed with $1 \%$ Triton X-100, $0.1 \%$ SDS, $0.15 \mathrm{M} \mathrm{NaCl}, 50 \mathrm{mM}$ Tris- $\mathrm{HCl}$ (pH 7.4), $2 \mathrm{mM}$ phenylmethylsulfonyl fluoride, and $1 \mathrm{mM}$ EDTA. Extracts were clarified by centrifugation at $15,000 \mathrm{rpm}$ at $4^{\circ} \mathrm{C}$ for $5 \mathrm{~min}$ and the supernatants were used immediately. Cell lysates were incubated for $90 \mathrm{~min}$ at $4^{\circ} \mathrm{C}$ with $50 \mu$ l of a $50 \%$ suspension of rabbit polyclonal anti-TNF antibody attached to sepharose beads. The antibody-bound sepharose beads were removed by centrifugation, washed five times with lysis buffer, and then twice with PBS. The immunoconcentrates were then ana- lyzed by SDS-PAGE; using $7.5 \%$ polyacrylamide slab gels with Tris glycine buffer (28). Gels were treated with Amplify TM (Amersham Corp., Arlington Heights, IL) for fluorography before drying. Autoradiography was performed at $-70^{\circ} \mathrm{C}$ using Kodak x-ray film.

\section{Results}

14 human epithelial tumor cell lines were tested for sensitivity to TNF growth inhibition. The results are listed in Table I. Resistance to TNF was defined as an $\mathrm{IC}_{50}$ of $>1,000 \mathrm{U} / \mathrm{ml}$ TNF in the 7-d growth inhibition assay. The three sensitive breast carcinoma cell lines (BT-20, MCF-7, and ZR-75-1) had $\mathrm{IC}_{50}$ of $<10 \mathrm{U} / \mathrm{ml}$ while all of the other eleven cell lines had $<50 \%$ growth inhibition at $1,000 \mathrm{U} / \mathrm{ml} \mathrm{TNF}$ and were considered to be resistant to the cytotoxic effects of TNF.

The cell lines were initially studied for the presence of TNF receptors by binding of ${ }^{125}$ I-labeled TNF. Analysis of the radioiodinated TNF by SDS/PAGE and autoradiography showed a single band with a $M_{\mathrm{r}}$ of 17,000 (Fig. $1 A$ ). Temperature and time course experiments indicated that maximum binding occurred after $2 \mathrm{~h}$ at $4^{\circ} \mathrm{C}$. Consequently, all binding studies were performed using these experimental conditions. The amount of ${ }^{125} \mathrm{I}$-TNF binding to TNF-sensitive $\mathrm{L}$ cells, TNF-resistant $\mathrm{L}$ cells, and the human epithelial tumor lines is shown in Fig. $1 B$. The sensitive L929 fibroblasts demonstrated specific ${ }^{125}$ I-TNF binding on the cell surface while the resistant L cells did not. Similarly, each of the three TNF-sensitive lines and 9 of the 11 TNF-resistant cell lines had specific ${ }^{125} \mathrm{I}-\mathrm{TNF}$ binding. This binding to the TNF-sensitive MCF-7 cells and to the TNF-resistant Ov-D cells were inhibited by various concentrations of unlabeled TNF. Scatchard analysis of these data gave apparent dissociation constants of $2.08 \times 10^{-10} \mathrm{M}$ and $2.56 \times 10^{-10} \mathrm{M}$ for the MCF-7 and Ov-D cells, respectively. The number of specific binding sites calculated by least-

Table I. TNF Growth Inhibition of Tumor Cell Lines In Vitro

\begin{tabular}{|c|c|c|}
\hline Cell type & $\mathrm{IC}_{50}$ & $\begin{array}{l}\% \text { Control growth } \\
\text { at } 10,000 \mathrm{U} \mathrm{TNF} / \mathrm{ml}\end{array}$ \\
\hline \multicolumn{3}{|c|}{$U / m l$} \\
\hline L929 wild & 1 & \\
\hline L929 resistant & $>10,000$ & 98.6 \\
\hline ZR-75-1 (breast) & 1 & \\
\hline MCF-7 (breast) & 2 & \\
\hline BT-20 (breast) & 5 & \\
\hline Ov-A (ovarian) & $>10,000$ & 60 \\
\hline Ov-D (ovarian) & $>10,000$ & 66 \\
\hline Ov-M (ovarian) & $>10,000$ & 79 \\
\hline Ov-S (ovarian) & $>10,000$ & 85 \\
\hline A549 (lung) & $>10,000$ & 71 \\
\hline Calu-3 (lung) & $>10,000$ & 62 \\
\hline Calu-6 (lung) & $>10,000$ & 85 \\
\hline NCI-69 (lung) & $>10,000$ & 83 \\
\hline ST-1 (stomach) & $>10,000$ & 72 \\
\hline Co-1 (colon) & $>10,000$ & 65 \\
\hline SCC-25 (oropharynx) & $>10,000$ & 97 \\
\hline
\end{tabular}

Sensitivity of tumor cell lines to the growth inhibitory effects of TNF. Each cell line was grown for $7 \mathrm{~d}$ in 96-well plates. The cells were fixed with $2.5 \%$ glutaraldehyde, stained with $0.05 \%$ methylene blue, and the absorbance at $600 \mathrm{~nm}$ read on an automated plate reader. All values are the mean of six replicates. 
A

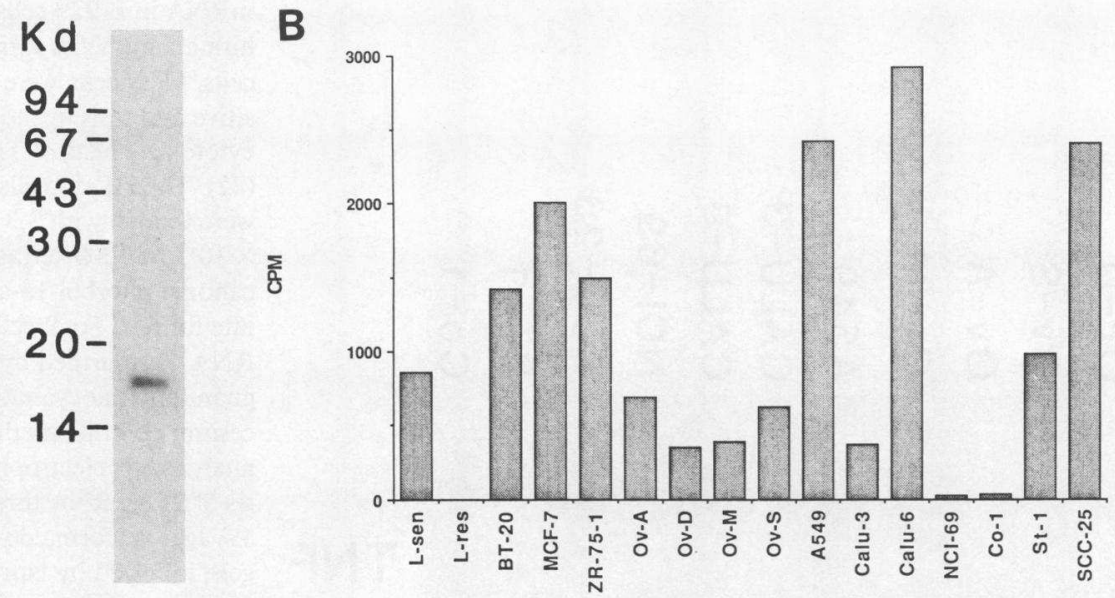

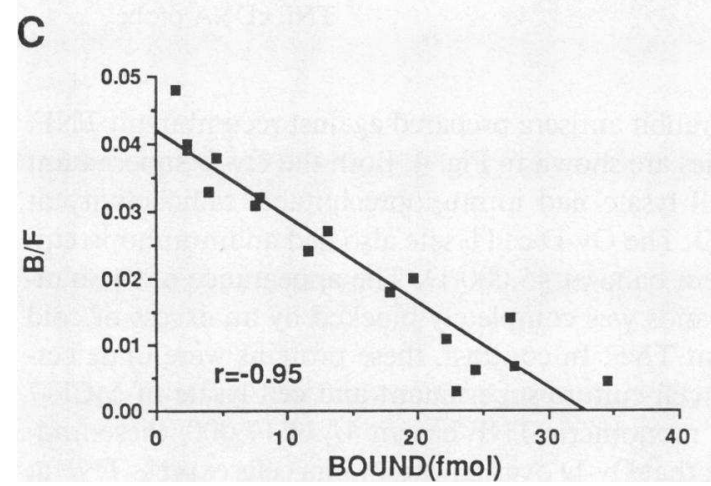

Figure 1. (A) SDS-PAGE analysis of ${ }^{125}$ I-TNF. Purified recombinant TNF was radioiodinated by the Iodogen method to a specific activity of $8.04 \mu \mathrm{Ci} / \mu \mathrm{g}$. The labeled TNF was then analyzed by SDS-PAGE and exposed to $\mathrm{x}$-ray film. $(B)$ Tissue culture cells were incubated for $120 \mathrm{~min}$ at $4^{\circ} \mathrm{C}$ with $40 \mathrm{pmol}{ }^{125} \mathrm{I}$-TNF. The cells were then washed, solubilized with $2 \%$ SDS, and monitored for radioactivity. Specific

squares regression from these data was 19,552 per MCF-7 cell and 3,160 per Ov-D cell (Fig. $1 C$ and $D$ ). These results are in concert with previous findings that resistance to TNF cytotoxicity is not necessarily related to the absence of TNF receptors. However, the resistant cell lines had generally lower single point specific binding values than did the sensitive tumor cell lines. This trend did not reach statistical significance (Student's $t$ test).

Recent studies have demonstrated that the induction of resistance to the cytotoxic effects of TNF is associated with TNF production in L929 cells and ZR-75-1 human breast carcinoma cells $(22,23)$. Levels of TNF mRNA in the epithelial tumor cell lines were therefore examined using total cellular RNA and Northern blot analysis. None of the three human cell lines sensitive to the cytotoxic effects of TNF had detectable TNF transcripts (Fig. 2). In contrast, the TNF cDNA probe hybridized to a 1.6-kb transcript in three of the eleven lines resistant to TNF cytotoxicity. Two of four ovarian carcinoma cell lines (Ov-A and Ov-D) and one of four lung carcinoma lines (NCI-69) had detectable amounts of TNF transcripts (Fig. 2). Resistant L cells, but not the wild type, sensitive $\mathrm{L}$ cells, also had detectable TNF mRNA (Fig. 2).
Studies on mouse monocytes have demonstrated that TNF production is regulated at both transcriptional and posttranscriptional levels (28). We have recently demonstrated that TNF expression in activated human monocytes is superinducible during inhibition of protein synthesis (unpublished data). In view of these findings, all 14 human epithelial cells were examined for the production of TNF transcripts in the presence of cycloheximide (Fig. 3). 1-3 h of cycloheximide induced detectable TNF transcripts in 12 of the 14 cell lines. Both TNF-sensitive and TNF-resistant epithelial cells demonstrated superinduction of TNF mRNA. The level of TNF mRNA expression was also increased in those cell lines that inherently expressed TNF transcripts. These findings would suggest that TNF expression in malignant epithelial cells is negatively regulated by a labile protein.

The detection of TNF transcripts in the epithelial tumor cell lines prompted further studies monitoring the expression of the gene product. Culture supernatants from each of the 14 human tumor cell lines $\left(10^{6}\right.$ cells $\left./ \mathrm{ml}\right)$ were examined for TNF production by ELISA. The limit of detection for recombinant TNF in this assay was $0.2 \mathrm{U} / \mathrm{ml}(5.3 \mathrm{pM})$. Using this approach, TNF was detectable in cell culture supernatants of phorbol 


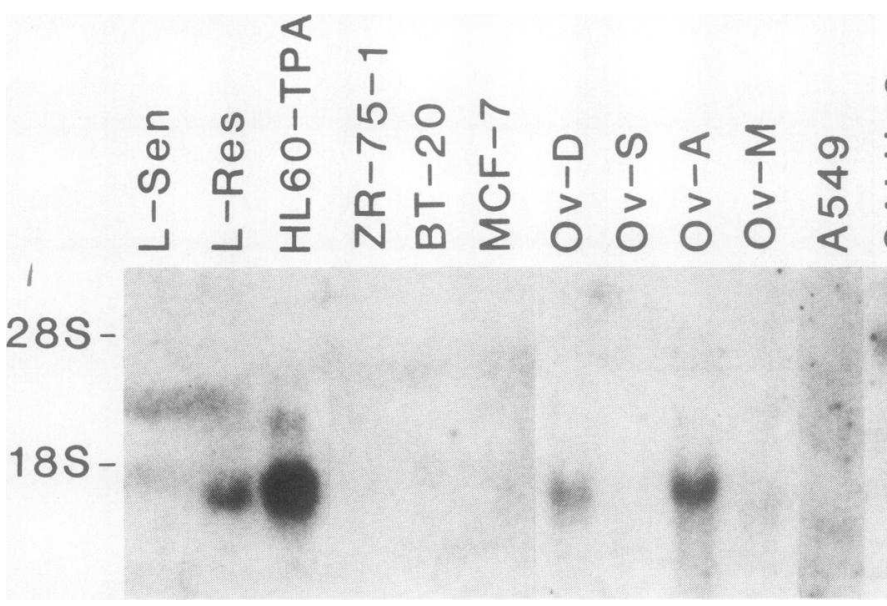

ester-stimulated monocytes. Immunoreactive TNF was not detectable in any of the culture supernatants from the 14 human epithelial tumor cells. Furthermore, cell lysates of each tumor cell line were also examined by ELISA and no detectable TNF was found. Western blot analysis of both cell culture supernatants and lysates obtained from each of the 14 human cell lines were also negative for TNF protein.

The absence of detectable TNF in supernatants of epithelial tumor cell lines may have been due to levels below the sensitivity of our assay. We therefore studied cytotoxic activity in cell culture supernatants using the L cell cytotoxicity assay (22). As recently reported, the resistant L cell culture supernatant was cytotoxic for $L$ cells (22). In contrast, no cytotoxic activity was present in the supernatant from any of the epithelial tumor cell lines. Even 50-fold concentrates of supernatants from the TNF resistant Ov-D ovarian cell line and the sensitive MCF-7 breast carcinoma line did not contain demonstrable cytotoxic activity for $\mathrm{L}$ cells.

The Ov-D and MCF-7 cells were further studied by protein labeling with $\left[{ }^{3} \mathrm{H}\right]$-leucine and immunoconcentration using
Figure 2. Levels of TNF mRNA in L-929 cells and human epithelial tumor cells. L929 cells were sensitive and resistant to the cytotoxic effects of TNF (22). The HL-60 cells were treated with 3.3 $\times 10^{-8} \mathrm{M} 12$-O-tetradecanonyl phorbol-13-acetate for $6 \mathrm{~h}$. Total cellular RNA was purified by the guanidine thiocyanatecesium chloride method, analyzed by electrophoresis of $20 \mu \mathrm{g}$ RNA through $1 \%$ agarose-formaldehyde gels, followed by Northern blot transfer to nitrocellulose and hybridization to the ${ }^{32} \mathrm{P}$-labeled TNF cDNA probe. polyclonal rabbit antisera prepared against recombinant TNF. These studies are shown in Fig. 4. Both the Ov-D supernatant and the cell lysate had immunoprecipitable radioactivity at $\sim$ 17,000 D. The Ov-D cell lysate also had an immunoprecipitable protein band at $45,000 \mathrm{D}$. The appearance of these radioactive bands was completely blocked by an excess of cold recombinant TNF. In contrast, these proteins were undetectable in the cell culture supernatant and cell lysate of MCF-7 cells. Since monomeric TNF has an $M_{\mathrm{r}}$ of 17,000 , these findings suggest that $\mathrm{Ov}-\mathrm{D}$ ovarian carcinoma cells express TNF at both the RNA and protein levels. The cell lysate of Ov-D cells also contained a second immunoreactive band at a $M_{\mathrm{r}}$ of 45,000 on SDS-PAGE. A similar immunoreactive $45-\mathrm{kD}$ protein was also identified by other workers during the purification and characterization of LuKII TNF (29).

\section{Discussion}

TNF is cytotoxic or inhibitory to a variety of human tumor cell lines $(19,21)$. Some cells that show growth inhibition by

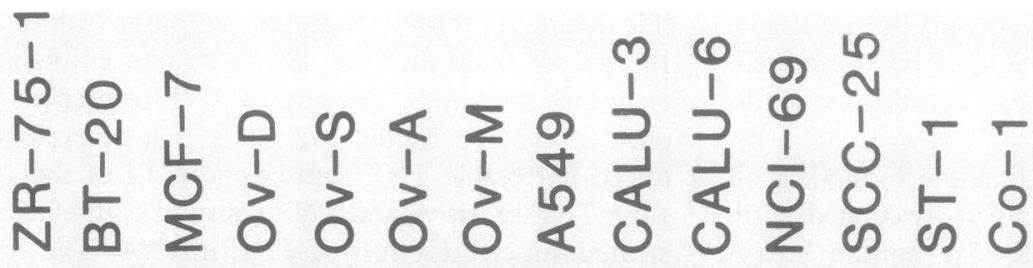

\section{S-}

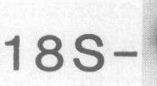

Figure 3. Effects of cycloheximide on TNF RNA expression in human epithelial tumor cells. Human epithelial tumor cell lines sensitive and resistant to the cytotoxic effects of TNF were treated with 10 $\mu \mathrm{g} / \mathrm{ml}$ cycloheximide (CH) for 1-3 h. Total RNA was then prepared and analyzed by Northern blots for hybridization to the ${ }^{32} \mathrm{P}$-labeled TNF cDNA probe. 


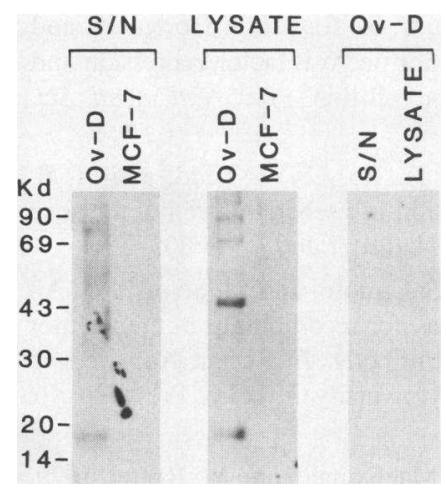

Figure 4. Detection of TNFlike protein in supernatant fluids and lysates of human epithelial tumor cell lines. MCF-7 and Ov-D cells were labeled overnight with $\left[{ }^{3} \mathrm{H}\right]-$ leucine. The supernatant fluids and cell lysates were incubated with rabbit anti-TNF antibody bound to sepharose beads. The immunoconcentrated fraction was analyzed by SDS-PAGE and autoradiography.

TNF alone are not sensitive to TNF cytolysis in the presence of cycloheximide, suggesting that growth inhibition and cytolysis may proceed by different mechanisms (30). These studies have focused on the direct growth inhibitory properties of TNF in the absence of protein synthesis inhibitors. High specificity cell surface receptors appear to be necessary but not sufficient for these cytotoxic and inhibitory effects $(16,17)$. High affinity cell surface receptors have been identified on normal cells as well as tumor cells both sensitive and resistant to the inhibitory or cytotoxic effects of TNF. Further, TNF-sensitive and -resistant tumor cells both internalize and degrade bound TNF (17). The basis for cellular sensitivity and resistance to the inhibitory effects of TNF are not known. Recent studies have suggested that exposure to low concentrations of TNF induce resistance to subsequent TNF/cycloheximide-mediated cytolysis (31). Both L929 cells and ZR-75-1 human breast carcinoma cells exposed to TNF for prolonged periods express a stable TNF resistance $(22,23)$. These TNF-resistant sublines secrete a TNF-like protein into the cell culture supernatant that is cytotoxic for L929 cells. Furthermore, in TNF-sensitive ZR-75-1 cells, TNF exposure will induce transient expression of TNF mRNA and protein (23). Taken together, these studies suggest that production of TNF by epithelial tumor cells resistant to TNF may represent a novel mechanism of resistance.

In the present study, $\mathbf{3}$ human epithelial tumor cell lines were sensitive to the growth inhibitory effects of TNF, while 11 were resistant. None of the 11 human epithelial tumor cell lines had been previously exposed to exogenous TNF. In contrast to the TNF-resistant L929 subline, 12 of the 14 epithelial tumor cell lines had detectable levels of ${ }^{125}$ I-TNF cell surface binding. The two tumor cell lines with minimal TNF binding (Co-1 and NCI-69) were both resistant to TNF growth inhibition. 3 of the 11 resistant tumor cell lines had detectable TNF mRNA while none of the 3 sensitive lines had TNF transcripts. These findings indicate that certain human epithelial tumor cell lines express TNF at the RNA and protein levels, and that expression of TNF may be associated with cellular resistance to the inhibitory effects of this cytokine. Of further note, most of the TNF-resistant cells and all of the sensitive cell lines express TNF mRNA after inhibition of protein synthesis by brief exposure to cycloheximide. These results indicate that common mechanisms regulate TNF gene expression in cells sensitive and resistant to the inhibitory effects of TNF. Two TNF-resistant cell lines, ST-1 and Co-1, did not express TNF mRNA, even after cycloheximide treatment, which suggests that more than one mechanism of control may be important for TNF gene expression. Studies using the run-off transcrip-

tion assays are underway to determine if the increase in TNF transcripts after cycloheximide treatment is due to enhanced transcription or mRNA stabilization. In monocytes, it appears that regulation of TNF production occurs through short-lived repressors which also regulate the expression of other genes such as IL-1 and urokinase (32).

The detection of TNF transcripts in 3 of the 11 TNF-resistant cell lines was not associated with production of detectable amounts of TNF protein using the ELISA or the L929 cell cytotoxicity assay. TNF product was, however, detectable after protein labeling and immunoprecipitation of both supernatant fluid and cell lysate from the Ov-D cell line. In contrast, TNF production was undetectable in TNF-sensitive MCF-7 cells that did not have detectable TNF transcripts. Taken together, these findings suggest that certain human tumor cells can produce both TNF mRNA and TNF protein. These cells retain TNF cell surface receptors. This constituitive production of TNF may be associated with resistance to in vitro TNF growth inhibition.

\section{Acknowledgments}

This work was supported by a grant from Asahi Chemical Industry America, Inc., by U. S. Public Health Service grant CA00994, awarded by the National Cancer Institute, Department of Health and Human Services (to D. R. Spriggs), and by a Burroughs Wellcome Award in clinical pharmacology (to D. W. Kufe).

\section{References}

1. Carswell, E. A., L. J. Old, R. L. Kassel, S. Green, N. Fiore, and B. Williamson. 1975. An endotoxin induced serum factor that causes necrosis of tumors. Proc. Natl. Acad. Sci. USA. 72:3666-3370.

2. Vilcek, J., V. J. Palmombella, D. Henriksen-DeStefano, C. Swenson, and R. Feinman. 1986. Fibroblast growth enhancing activity of tumor necrosis factor and its relationship to other polypeptide growth factors. J. Exp. Med. 163:632-643.

3. Klebanoff, S. J., M. A. Vadas, J. M. Harlan, L. H. Sparks, and J. R. Gamble. 1986. Stimulation of neutrophils by tumor necrosis factor. J. Immunol. 136:4220-4225.

4. Tsujimoto, M., S. Yokota, J. Vilcek, and H. Weissmann. 1986. Tumor necrosis factor provokes superoxide anion generation from neutrophils. Biochem. Biophys. Res. Commun. 137:1094-1100.

5. Shalaby, M. R., B. B. Aggarwal, E. Rinderknecht, L. P. Sverdersky, B. S. Finkle, and M. A. Palladino. 1985. Activation of human polymorphonuclear neutrophil functions by interferon-gamma and tumor necrosis factors. J. Immunol. 135:2069-2073.

6. Silberstein, D. S., and J. R. David. 1986. Tumor necrosis factor enhances eosinophil toxicity to schistosoma mansoni larvae. Proc. Natl. Acad. Sci. USA. 83:1055-1059.

7. Bachwich, P. R., S. W. Chensue, J. W. Larrick, and S. L. Kunkel. 1986. Tumor necrosis factor stimulates interleukin 1 and prostaglandin E2 production in resting macrophages. Biochem. Biophys. Res. Commun. 136:94-101.

8. Urban, J. L., M. Shepard, J. L. Rothstein, and B. J. Sugarman. 1986. Tumor necrosis factor: a potent effector molecule for tumor cell killing by activated macrophages. Proc. Natl. Acad. Sci. USA. 83:5233-5237.

9. Bertolini, D. R., G. E. Nedwin, T. S. Bringman, D. D. Smith, and G. R. Mundy. 1986. Stimulation of bone resorption and inhibition of bone formation in vitro by human tumor necrosis factor. Nature (Lond.). 319:516-518.

10. Munker, R., J. Gasson, M. Ogawa, and H. P. Koeffler. 1986. Recombinant human tumor necrosis factor induces production of granulocyte monocyte colony stimulating factor. Nature (Lond.). 323:79-82.

11. Torti, F. M., B. Dieckmann, B. Beutler, A. Cerami, and G. M. 
Ringold. 1985. A macrophage factor inhibits adipocyte gene expression: an in vitro model of cachexia. Science (Wash. DC). 229:867-871.

12. Dayer, J. M., B. Beutler, and A. Cerami. 1985. Cachectin/ tumor necrosis factor stimulates collagenase and prostaglandin E2 production by human synovial cells and dermal fibroblasts. J. Exp. Med. 162:2163-2168.

13. Nawroth, P. P., and D. M. Stern. 1986. Modulation of endothelial cell hemostatic properties by tumor necrosis factor. J. Exp. Med. 163:740-745.

14. Beutler, B. A., I. W. Milsark, and A. Cerami. 1985. Passive immunization against cachectin/tumor necrosis factor protects mice from lethal effect of endotoxin. Science (Wash. DC). 229:869-871.

15. Tracey, K. J., B. Beutler, S. F. Lowry, J. Merryweather, S. Wolpe, I. W. Milsark, R. J. Hariri, T. J. Fahey, A. Zentella, J. D. Albert, G. T. Shires, and A. Cerami. 1986. Shock and tissue injury induced by recombinant human cachectin. Science (Wash. DC). 234:468-474.

16. Kull, F. C., S. Jacobs, and P. Cuatrecasas. 1985. Cellular Receptor for 125-I-labeled tumor necrosis factor: specific binding, affinity labeling, and relationship to sensitivity. Proc. Natl. Acad. Sci. USA. 82:5756-5760.

17. Tsujimoto, M., Y. K. Yip, and J. Vilcek. 1985. Tumor necrosis factor: specific binding and internalization in sensitive and resistant cells. Proc. Natl. Acad. Sci. USA. 82:7626-7630.

18. Darzynkiewicz, Z., B. Williamson, E. Carswell, and L. J. Old. 1984. Cell cycle specific effects of tumor necrosis factor. Cancer Res. 44:83-90.

19. Williamson, B. D., E. A. Carswell, B. Y. Rubin, J. S. Prendergast, and L. J. Old. 1983. Human tumor necrosis factor produced by human B-cell lines: synergistic cytotoxic interaction with human interferon. Proc. Natl. Acad. Sci. USA. 80:5397-5401.

20. Kirstein, M., W. Fiers, and C. Baglioni. 1986. Growth inhibition and cytotoxicity of tumor necrosis factor in L929 cells is enhanced by high cell density and inhibition of mRNA synthesis. J. Immunol. 137:2277-2280.

21. Aggarwal, B. B., T. E. Essalu, and P. E. Hass. 1985. Characterization of receptors for human tumour necrosis factor and their regulation by gamma-interferon. Nature (Lond.). 318:665-667.

22. Rubin, B. Y., S. L. Anderson, S. A. Sullivan, B. D. Williamson, E. A. Carswell, and L. J. Old. 1986. Nonhematopoietic cells selected for resistance to tumor necrosis factor. J. Exp. Med. 164:1350-1355.
23. Spriggs, D. R., K. Imamura, C. Rodriguez, J. Horiguchi, and D. W. Kufe. 1987. Induction of tumor necrosis factor expression and resistance in a human breast tumor cell line. Proc. Natl. Acad. Sci. USA. 84:6563-6566.

24. Shirai, T., H. Yamaguchi, H. Ito, C. W. Todd, and R. B. Wallace. 1985. Cloning and expression in Escherichia coli of the gene for human tumour necrosis factor. Nature (Lond.). 313:803-806.

25. Hayashi, H., T. Kiyota, H. Sakamoto, and M. Seto. 1985. An enzyme-linked immunosorbent assay for recombinant human tumor necrosis factor using monoclonal antibody. In Recent Advances in Chemotherapy. J. Ishigami, editor. University Of Tokyo Press, Tokyo. 820-822.

26. Chirgwin, J., H. Przybla, R. MacDonald, and W. Rutter. 1979. Isolation of biologically active ribonucleic acid from sources enriched in ribonuclease. Biochemistry. 18:5294-5299.

27. Wang, A., A. Creasey, M. Ladner, L. Lin, J. Strickler, J. N. Vanarsdell, R. Yamamoto, and R. D. Mark. 1985. Molecular cloning of the complementary DNA for human tumor necrosis factor. Science (Wash. DC). 228:149-154.

28. Beutler, B., N. Krochlin, I. W. Milsark, C. Leudke, and A. Cerami. 1986. Control of cachectin (tumor necrosis factor) synthesis: mechanisms of endotoxin resistance. Science (Wash. DC). 232:977980.

29. Rubin, B. Y., S. L. Anderson, S. A. Sullivan, B. D. Williamson, E. A. Carswell, and L. J. Old. 1985. Purification and characterization of a human tumor necrosis factor from the LuKII cell line. Proc. Natl. Acad. Sci. USA. 82:6637-6641.

30. Ruggerio, V., K. Latham, and C. Baglioni. 1987. Cytostatic and cytotoxic activity of tumor necrosis factor on human cancer cells. $J$. Immunol. 138:2771-2717.

31. Hahn, T., L. Toker, S. Budilovsky, D. Aderka, Z. Eshhar, and D. Wallach. 1985. Use of monoclonal antibodies to a human cytotoxin for its isolation and for examining the self-induction of resistance to this protein. Proc. Natl. Acad. Sci. USA. 82:3814-3818.

32. Collart, M. A., D. Belin, J. D. Vassalli, S. Kossado, and P. Vassalli. 1986. Gamma-interferon enhances macrophage transcription of the tumor necrosis factor/cachectin, interleukin 1 and urokinase genes, which are controlled by short lived repressors. J. Exp. Med. 164:2113-2118. 